\title{
Multiple Scenarios Forecast of Electric Power Substitution Potential in China: From Perspective of Green and Sustainable Development
}

\author{
Jing Wu 1,2, , Zhongfu Tan ${ }^{1,2,3}$, Gejirifu De ${ }^{1,2}$, Lei Pu ${ }^{1,2}$, Keke Wang ${ }^{1,2}$, Qingkun Tan ${ }^{4}$ and \\ Liwei Ju ${ }^{1,2}$ \\ 1 School of Economics and Management, North China Electric Power University, Beijing 102206, China \\ 2 Beijing Key Laboratory of New Energy and Low-Carbon Development, North China Electric Power \\ University, Beijing 102206, China \\ 3 School of Economics and Management, Yan'an University, Yan'an 716000, China \\ 4 State Grid Energy Research Institute Co., Ltd., Changping District, Beijing 102209, China \\ * Correspondence: 1182106009@ncepu.edu.cn; Tel.: +86-178-0113-7856
}

Received: 1 August 2019; Accepted: 27 August 2019; Published: 2 September 2019

\begin{abstract}
To achieve sustainable social development, the Chinese government conducts electric power substitution strategy as a green move. Traditional fuels such as coal and oil could be replaced by electric power to achieve fundamental transformation of energy consumption structure. In order to forecast and analyze the developing potential of electric power substitution, a forecasting model based on a correlation test, the cuckoo search optimization (CSO) algorithm and extreme learning machine (ELM) method is constructed. Besides, China's present situation of electric power substitution is analyzed as well and important influencing factors are selected and transmitted to the CSO-ELM model to carry out the fitting analysis. The results showed that the CSO-ELM model has great forecasting accuracy. Finally, combining with the cost, policy supports, subsidy mechanism and China's power consumption data in the past 21 years, four forecasting scenarios are designed and the forecasting results of 2019-2030 are calculated, respectively. Results under multiple scenarios may give suggestions for future sustainable development.
\end{abstract}

Keywords: electric power substitution; potential forecasting; CSO-ELM; green sustainable development

\section{Introduction}

With the rapid growth of economy and the increasing consumption of fossil resources, China is facing problems of resource shortage, climate change and environmental governance [1], showing an increasing contradiction between social development and unsustainable energy structure. The overdose of coal combustion, large number of automotive exhaust emissions and improper treatment of pollutants are all leading to serious atmospheric pollution, which seriously threatens the quality of people's lives and has an irreversible impact overall on the ecological environment [2]. In order to mitigate the effects of pollution emissions, it is urgent to develop and promote highly efficient and green energy technologies in order to reach social sustainability. According to China Energy Statistical Yearbook (2017), 50\% to $60 \%$ of particulate matter 2.5 (PM 2.5) air pollution comes from coal combustion and $20 \%$ to $30 \%$ from oil combustion. Meanwhile, the National Development and Reform Commission and the National Energy Administration of China has proposed that, by 2020, the total amount of electricity replacing coal and oil combustion is estimated to reach 130 million tons of standard coal, and the proportion of electric energy in the end-stage energy consumption should be $27 \%$, increasing by about $1.5 \%$. The additional consumption of electricity in the "13th Five-Year Plan" is set to be 
450 billion kWh [3]. Under the global trend of low-carbon green development, "Two substitutions", which includes both clean-energy substitution and electric power substitution, is meant to guide the energy structure optimal reform [4]. Therefore, studies on electric power substitution potential will give suggestions and guidance for its further sustainable development.

As an energy consumption pattern [5], electric power substitution can make further use of the environmental capacity in different regions, in order to reach the balance of pollutants emissions and optimal resources allocation [6,7]. By replacing coal and fuel with electric power, pollutions can be effectively cut down and energy efficiency improved [8]. With the development of energy technology revolution, electric power substitution can be applied into transportations, electric boilers, electric kilns, electric heating and electric cookers, replacing fossil resources such as oil and coal. At present, the industrial energy efficiency is relatively low. Clean energy substitution would effectively improve the efficiency of energy utilization [9]. The market potential for promoting electric power substitution in China is about 22 trillion $\mathrm{kWh}$. The potential of substituting coal and oil with electricity is prospectively 18 trillion and 400 billion $\mathrm{kWh}$, showing huge potential of the substitution market. Presently, electric power substitution is gradually becoming a research focus both in China and globally. Scholars have made achievements regarding electric power substitution with two different approaches: one is the technical and economic research of the power substitution, and the other is related to methods used for forecasting.

By analyzing the technical and economic efficiency of energy substitutions, Wu et al. [10] proposed that the sustainable use of energy would be the main direction of future development. Based on the system dynamics model, Song et al. [11] analyzed the emission reduction effect of the renewable energy substitution in China. Besides, while researching energy substitution, many scholars achieved energy substitutions on the power supply side by combining multiple renewable energy resources [12]. He et al. [13] introduced the environmental utility in the environmental consumption (EUEC) model to discuss the relationship between urban energy consumption and environmental utility changes. Barreto [14] demonstrated the dynamic substitution effect of renewable energy replacing fossil fuel by building a theoretical framework that incorporates alternative energy and traditional fossil energy into the endogenous growth model. Liu et al. [15] established a dynamic system model combining multiple renewable energy sources and made an empirical analysis. By changing the proportion of electric vehicles in the power system, André et al. [16] compared and analyzed the emission reduction benefits of the system under multiple scenarios. Kumar et al. [17] discussed the innovative capabilities that enterprises need to adopt, such as pollution prevention and clean technology strategies, in order to achieve sustainable development.

The development of electric power substitution is influenced by many factors, such as technology, economy, environmental protection requirements, policy measures, demand response, etc. Wu et al. [18] pointed out that the initial investment was high; therefore, promoting the projects is facing greater resistance. Similarly, Shaligram [19] argued that the current barriers to substitution mainly contained the high cost of substitute technology. By summarizing the practical experience in the Jiangsu Province, Li [20] found that there were some problems in the promotion work, such as insufficient policy support, less response from users and lower technology level. Combined with various factors, Liang et al. [21] constructed the evaluation index model of power substitution scheme and analyzed its substitution potential. Lu and Xie [22] empirically analyzed the intensity of enterprises conducting clean substitution under the pressure of carbon emission reduction. Faced with the carbon emission reduction, the sense of conducting cleaner production will increasingly rise.

For forecasting methods, many scholars have made many achievements. Common methods include single forecasting models and combined forecasting models, such as Support Vector Machine (SVM), artificial neural network, genetic algorithm, grey forecasting model, and a combination of forecasting methods. Wei et al. [23] combined a neural network and statistical linear model to predict wind power output. Michael et al. [24] incorporated the forecasting model based on machine learning to predict the household energy consumption. Zhang et al. [25] proposed a forecasting model for 
building demand response with random forest and ensemble learning method. Wu et al. [26] forecasted the short-term load of a power system based on generalized regression neural network method. Based on artificial neural network method, Xia et al. [27] combined a virtual instrument and radial basis function neural network and created long-term, medium-term and short-term load forecasting. Shan et al. [28] used the extremum learning machine (ELM) method based on Back Propagatio (BP) and SVM to forecast photovoltaic (PV) generation. Chen and Yu [29] used SVM on wind signal prediction. Lee and Tong [30] combined grey model and incorporating genetic algorithm together to forecast and analyze the demand for electric power. A hybrid model composed by SVM and a Seasonal Auto Regressive Integrated Moving Average was proposed for short-term PV generation forecasting [31]. $\mathrm{Yu}$ and $\mathrm{Xu}$ [32] used an optimized genetic algorithm and improved BP neural network (BPNN) to forecast the load of natural gas. In the actual implementation process of power substitution work, an accurate forecast on power consumption and the changing trend can provide data support and policy guidance for further power substitution work promoting [33,34]. Sun et al. [35] forecasted the potential of power substitution using particle swarm optimization (PSO)-SVM. Yin [36] established a grey energy demand-forecasting model to forecast the terminal energy demand in Beijing. Zheng [37] constructed the potential forecasting model on rural electric power substitution, and made middle and long-term analysis of electricity consumption. $\mathrm{Li}$ [38] used the improved TOPSIS method to analyze the potential of regional power substitution.

Above all, scholars have made achievements in presenting electric power substitution, promoting methods and digging related influencing factors [39]. However, few have mentioned the developing potential forecast of the substitution works. Most existing works on potential analysis used the comprehensive evaluation method, which cannot show the future developing trend of the power substitutions. Therefore, in order to make up for the deficiencies of the existing research on the potential analysis of power substitution, a CSO-ELM model based on the Pearson correlation test is constructed to forecast the market potential of electric power substitution projects. The main contributions of this work are summarized as follows.

(1). To overcome the limitation of single algorithms, a forecasting algorithm combining Cuckoo Search Optimization (CSO) and Extreme Learning Machine (ELM) is constructed, which can make full use of the superior global search ability of the Cuckoo algorithm and the learning efficiency and generalization ability ELM. The proposed algorithm is highly sensitive to the market potential of power substitution projects and can accurately reflect the development potential.

(2). Starting from the current electric power substitution in China, factors that affect the promotion of electric power substitution projects, such as economy, policy and technology are analyzed systematically, so as to make up for the deficiency of the existing research on the influencing factors analysis of electric power substitution potential.

(3). A relevance test is conducted to choose effective influencing factors. Factors with a significant influencing level will be taken as input factors of the forecasting model, and factors with insignificant or general influencing degree are excluded.

(4). The validity and superiority of the forecasting model are verified by the actual situation of China's electric power substitution. some feasible suggestions are put forward based on the forecasting results under multiple scenarios to promote the orderly progress of electric power substitution work.

The paper is organized as follows: Section 2 presents the structures and features of the forecasting method. Section 3 introduces the current situation of the electric power substitution in China and gives summary of all influencing factors. In Section 4, specific data is used to verify the effectiveness of the proposed method, and four scenarios are given to address further discussion of the future development of the substitution work. Finally, the conclusion is given in Section 5. 


\section{Current Situation and Influencing Factors Selection of Electric Power Substitution in China}

\subsection{Current Situation of Electric Power Substitution}

The rapid growth of China's economy is accompanied by excessive energy consumption. In order to narrow the gap of energy utility between China and developed countries, the concept of energy conservation should be penetrated through energy exploitation, transportation and utilization. Proper use of energy and improving energy efficiency are the main goals of energy development in the future. Electric power substitution projects have great development potential in the future.

Electric power substitution uses electric power to replace coal-fired heating. Through the large-scale centralized conversion of power, electric power substitution can improve the efficiency of fuel use and reduce pollutant emissions to optimize the terminal energy structure and promote environmental protection. Electric power substitutions include coal substitution by electricity, oil substitution by electricity, and electrification of agricultural production, etc. Different substitution methods for each field are shown in the Table 1 below.

Table 1. Electric power substitution methods.

\begin{tabular}{ll}
\hline Substitution Fields & Substitute Methods \\
\hline \multirow{3}{*}{ Substitute Coal by Electricity } & Electric heating replacing coal-fired heating \\
& Electric boiler replacing industry coal-fired boiler \\
& Electrification in family and catering industry \\
\hline \multirow{3}{*}{ Substitute Oil by Electricity } & Electric vehicles replacing fossil-fueled vehicles \\
& Electric pump replacing agricultural oil pump \\
& Shore power supply replacing diesel engines \\
\hline Substitute Gas by Electricity & Electricity replacing natural gas \\
\hline Power Trans-Regional Transmission & Long-distance transmission of clean power \\
\hline
\end{tabular}

Despite various methods to promote electric power substitution, scientific and reasonable policies are necessary in promoting the substitution work. Since 2015, the Chinese government has promulgated 226 supporting policies to encourage electric power substitution, guiding the society to choose electric energy actively, and gradually eliminate the high pollution and low efficiency of energy use. Government support is not only subjective to propaganda and guidance, but also to strengthen the construction of electric power to improve the competitiveness of electricity continuously in power market. The relevant electricity alternative development policies are shown in the Table 2 below.

As can be seen from Table 2, a good policy environment has been provided to develop energy substitutions. The government issued guidance on electric power substitution promotion, using the substitution work as a national strategy. Then, supporting policies came to support the pilot work of clean energy heating in winter in northern areas, to promote the prevention and control of air pollution in Beijing-Tianjin-Hebei Region and the surrounding areas. Electric power substitution has been regarded as an important part of the national "13th Five-Year Plan" in the electricity industry and modern comprehensive transportation system. 
Table 2. Policies supporting electric power substitution work

\begin{tabular}{|c|c|c|}
\hline Policies & Year & Contents \\
\hline $\begin{array}{l}\text { Guidelines for Improving Power System } \\
\text { Regulation Capability }\end{array}$ & 2018 & $\begin{array}{l}\text { Comprehensively promote electric power substitution. By } 2020 \text {, the aim is to achieve } \\
450 \text { billion kWh of the substituting electricity, and the electricity consumption accounts } \\
\text { for } 27 \% \text { of the total energy consumption. }\end{array}$ \\
\hline $\begin{array}{l}\text { Guidelines on Promoting Clean Energy Heating in } \\
\text { Cities and Towns in Northern China }\end{array}$ & 2017 & $\begin{array}{l}\text { Promote the work of "coal to gas", "coal to electricity" and renewable energy heating in } \\
\text { " } 2+26 \text { " cities in Beijing-Tianjin-Hebei region and the surrounding areas to improve the } \\
\text { efficiency of clean energy heating }\end{array}$ \\
\hline $\begin{array}{l}\text { Demand Side Management in Electricity } \\
\text { Industry (Revised) }\end{array}$ & 2017 & $\begin{array}{l}\text { Promote the electricity work in the demand side to help control air pollution and } \\
\text { expand electricity consumption. Bring innovations to electric power substitution work } \\
\text { and create new methods and the substituting fields to expand the promoting scale. }\end{array}$ \\
\hline $\begin{array}{l}\text { Work Plan for Air Pollution Control and Prevention in } \\
\text { Beijing-Tianjin-Hebei and Surrounding Areas in } 2017\end{array}$ & 2017 & $\begin{array}{l}\text { Support the heating and gas substituted projects that provide services for residents' } \\
\text { livelihood, and give capital supports for equipment purchasing. }\end{array}$ \\
\hline $\begin{array}{l}\text { "13th Five-Year Plan" of Comprehensive Work on } \\
\text { Energy Conservation and Emission Reduction" }\end{array}$ & 2017 & $\begin{array}{l}\text { During the "13th Five-Year Plan" period, the proportion of electric energy in the } \\
\text { consumption of terminal energy should be continuously increased. The construction of } \\
\text { charging facilities should be pushed forward. Promote central electric heating to } \\
\text { replace small coal-fired boilers gradually. }\end{array}$ \\
\hline $\begin{array}{l}\text { Intensive Plan for Air Pollution Prevention and Control } \\
\text { in Beijing-Tianjin-Hebei Region }\end{array}$ & 2016 & $\begin{array}{l}\text { Promote the clean energy substitution work in rural areas of } \\
\text { Beijing-Tianjin-Hebei Region. }\end{array}$ \\
\hline Guidelines on Promoting Electric Power Substitution & 2016 & $\begin{array}{l}\text { Electric power substitution will be promoted in the four key areas, such as heating in } \\
\text { northern areas, production and manufacturing, transportation, power supply and } \\
\text { consumption. }\end{array}$ \\
\hline $\begin{array}{l}\text { Notice on Further Pilot Work of Energy Conservation } \\
\text { and New Energy Vehicle Demonstration and Promotion }\end{array}$ & 2016 & $\begin{array}{l}\text { Encourage the development of new energy vehicles and electric vehicles, and mobilize } \\
\text { the enthusiasm of all units to use energy-saving and new energy vehicles. }\end{array}$ \\
\hline
\end{tabular}


With the creation of new policies, the scale of electric power substitution has been expanding. Implementation plans of electric power substitution have come out as well. Presently, China's electric power substitution projects are mainly carried out in the field of substituting coal and oil. Electric heating and electric vehicles—as the main alternative methods-have achieved remarkable results. In 2017, 101,807 electric power substitution projects were implemented nationwide, with 128.6 billion $\mathrm{kWh}$ of electricity in all substituting fields. Among them, 8.8 billion $\mathrm{kWh}$ comes from residential heating, 77.4 billion $\mathrm{kWh}$ from industrial (agricultural) production and manufacturing, 12.8 billion $\mathrm{kWh}$ from transportation, 23.9 billion $\mathrm{kWh}$ from electric power supply and consumption, and 5.8 billion $\mathrm{kWh}$ from household electrification and other fields, which is equivalent to a reduction of 64.4 million tons of coal-fired burning. The emission reduction is about 110 million tons of carbon dioxide, 5.2 million tons of sulfur dioxide and nitrogen oxides.

\subsection{Analysis on Influencing Factors of Electric Power Substitution Potential}

With the development of global energy internet, electric power substitution is facing new opportunities. The substitution work is affected by energy consumption, GDP, energy prices, investment in renewable power assets and average concentration of P.M. 2.5 and other factors.

(1). Electricity consumption

Electricity consumption is an important index used to measure the level of national electrification. Electrification represents the proportion of electric power, and reflects the changes of social energy consumption structure. The increase of electricity consumption directly leads to the improvement of social electrification. Meanwhile, the improvement of electrification shows an increase in social energy-use technology, which can effectively reduce the cost of electric power substitution projects and reach further promotion of electric power substitution.

(2). GDP per capita

GDP is an important indicator reflecting the economic development in China, which is an important factor affecting the demand of electricity. The economy of a region will have impacts on electricity and other energies' consumption. Research on power and energy has been made, and scholars have regarded GDP per capita as the decisive factor affecting electricity demand, which means that China's electricity demand and GDP growth are endogenous with a significant and stable relationship. In addition, the rise in GDP can promote residents' living standards. As people are becoming richer, they may pay more attention to the energy structure. Thus, the promotion of electric power substitution can be further improved. Therefore, GDP per capita is chosen as an indicator to show the impact of economic development on power substitution in China.

(3). Annual investment increment in electric power industry

The relationship between the investment in electric power industry and social electricity consumption is positive. Investing in electric power assets shows the attention society attaches to the development of the electric power industry. The investment in the electric power industry includes investment in power grid construction and investment in generators. Both will bring an increase in electricity consumption, which can indirectly improve the replacing effects of electricity to other energy resources. Two indicators-the annual investment increment in electric power industry and in power grid construction-are chosen in the following analysis.

(4). Electric power installed capacity

The electric power installed capacity is proportional to the total generating capacity, which helps promote electric power substitution work. In addition, renewable power generation has lower operating costs and less pollution emissions. Substituting fossil resources with renewable power will further improve the social benefits and achieve pollution reduction from power supply side. Therefore, as an important indicator, electric power installed capacity of renewable energy is considered in forecasting the market potential of electric power substitution projects.

(5). Renewable power generation 
Renewable energy utilization is significant to energy structure adjustment under low-carbon mechanism. Using clean energies to generate will effectively reduce the proportion of coal-fired thermal power, thereby reducing the environmental burden. Besides, integrating more renewable power into the substitution work will help with the power curtailment problem, and large-scale utilization of renewable energy achieves substitutions for traditional fuels from the generation side. Thus, the implementation scope of electric power substitutions will be further expanded, and the environmental benefits will be significantly improved.

(6). Carbon emissions

The rising carbon emissions has forced the government and all sectors of society to pay more attention to the energy consumption structure. According to China's "National Independent Contribution" in 2030 — compared with the situation in 2005—carbon dioxide emissions should achieve the peak value, carbon dioxide emissions per unit GDP will decrease by $60 \%$ to $65 \%$ and the proportion of non-fossil energy in primary energy consumption should reach about $20 \%$. Facing the double pressures of international emission reduction commitments and domestic resources and environment, promoting clean energy usage is an important means to achieve carbon emission reduction. Constrained by carbon emission targets, enterprises' awareness of environmental protection will raise. With the development of clean technology, the electric power substitution work shall be promoted in large scale [22].

\section{Methodology}

\subsection{Pearson Test}

Pearson correlation coefficient is a method used to measure the degree of correlation between two variables. The correlation value is between 1 and -1 , where 1 means that variables are completely positive, 0 means irrelevant, and -1 means completely negative. The correlation value between $(X, Y)$ is calculated as follows.

$$
\begin{aligned}
P_{x, y} & =\frac{\operatorname{cov}(X, Y)}{\sigma_{X} \sigma_{Y}}=\frac{E\left(\left(X-\mu_{X}\right)\left(Y-\mu_{Y}\right)\right)}{\sigma_{X} \sigma_{Y}} \\
& =\frac{E(X Y)-E(X) E(Y)}{\sqrt{E\left(X^{2}\right)-E^{2}(X)} \sqrt{E\left(Y^{2}\right)-E^{2}(Y)}}
\end{aligned}
$$

The numerical value of $P_{x, y}$ reflects the linear correlation degree of $Y$ and $X$, which is between $[-1,1]$. The conclusion is as follows.

(1). When $\left|P_{x, y}\right| \rightarrow 1$, the correlation between $Y$ and $X$ is stronger.

(2). When $\left|P_{x, y}\right| \rightarrow 0$, the correlation between $Y$ and $X$ is weaker, or non-linear related, even when not related.

\subsection{Cuckoo Search Optimization}

Enlighted by the brood parasitism behaviors of cuckoo birds, the Cuckoo Search optimization (CSO) algorithm, which is a natural heuristic algorithm developed by Yang in 2009 [40]. The cuckoo bird lays eggs in the nest of the host-bird's nest and removes the eggs of the host. Occasionally, some cuckoo eggs look similar to host eggs and get the opportunity to be raised. In other cases, these eggs may be found by the host birds, who will throw them away or leave the nests to find other places to build new nests. Each egg in a nest represents a solution, and a cuckoo egg stands for a new solution. $\mathrm{CSO}$ uses new and potentially better solutions to replace not-so-good solutions in the nests.

The CSO method operates as follows. The cuckoo lays only one egg at a time and randomly places the egg in a nest. The nest with the highest quality egg (the solution to the problem) will remain to the next turn. The number of the nests which can be laid eggs in is fixed, and the probability that the host bird can select the cuckoo eggs is $p_{a} \in[0,1]$.

Under this situation, the host bird can choose to throw the cuckoo eggs or find a new nest to replace the old one. If not detected, the cuckoo eggs will be successfully hatched up and find new hatching sites through Lévy flight. Considering the Lévy flight behavior of the cuckoo birds' nest-seeking 
feature, assume that there are $N$ cuckoo eggs in the $D$-dimensional search space. The location of the number $i$ egg under the $k$ th iteration is $x_{i}^{k}$, and the new solution $x_{i}^{k+1}$ can be expressed as follows.

$$
\begin{gathered}
x_{i}^{k+1}=x_{i}^{k}+\delta_{i} \\
\delta_{i}=\alpha \times s_{i} \oplus\left(x_{i}^{k}-x^{b e s t}\right),
\end{gathered}
$$

where, $\alpha>0$ is the step size, which relates to the scale of the problem. $\delta_{i}$ is the changing amount of position that needs to be taken, and $\oplus$ is the entry wise multiplications.

The random step is produced by the symmetric Lévy distribution.

$$
s_{i}=\frac{u}{|v|^{1 / \beta}}
$$

where, $u\left(u_{1}, u_{2}, \cdots, u_{d}\right), v\left(v_{1}, v_{2}, \cdots, v_{d}\right)$ are vectors in the $D$-dimensional space. $\beta=3 / 2$. The sub-vectors of $u$ and $v$ obey normal distribution.

$$
\begin{gathered}
u \sim N\left(0, \sigma_{u}^{2}\right), v \sim N\left(0, \sigma_{v}^{2}\right) \\
\sigma_{u} \sim\left(\frac{\Gamma(1+\beta) \cdot \sin (\pi \cdot \beta / 2)}{\Gamma((1+\beta) / 2) \cdot \beta \cdot 2^{(\beta-1) / 2}}\right)^{1 / \beta}, \sigma_{v}=1 .
\end{gathered}
$$

Lévy flight includes a random directional linear motion sequence with no characteristic scale, and the step size of each sequence satisfies the heavy-tailed distribution. The relatively short straight-line move with a larger frequency will be intermittently replaced by the longer-step move with less frequency. Lévy flight ensures the comprehensiveness of searching, so that the search efficiency of $\mathrm{CSO}$ is higher than that of the standard Gauss random processes.

\subsection{Extreme Learning Machine}

ELM, proposed by Professor Huang in 2004, is a fast and efficient single-layer feedforward neural network algorithm. ELM is essentially a linear-in-the-parameter model, so its learning process is easy to converge to the global minimum. Due to the random input weights and hidden layer thresholds, the number of hidden layer nodes significantly influence the performance of the model. For a Single-hidden Layer Feedforward Neural network (SLFN), ELM uses the number of hidden layers to train-which greatly reduces the training time and computational complexity. The main idea of the ELM model is to randomly set the network weights and then obtain the inverse output matrix of the hidden layer. Compared with other learning models, the ELM model operates extremely fast and maintains a better accuracy and has therefore been widely used in many fields. In the ELM training process, the number of neurons in the hidden layer is the only need. Therefore, the output weight matrix of the hidden layer can be calculated without adjusting the connection weight between the input layer neurons and the hidden layer neurons and the deviation of the hidden layer neurons.

The network-training model of extreme learning machine adopts the former single hidden layer structure. Assuming there are $N$ sets of initial training set $\left(x_{i}, t_{t}\right)$, the input layer includes $x_{i}=\left[x_{i 1}, x_{i 2}, \ldots x_{i n}\right]^{\mathrm{T}} \in R^{n}$, and the target output layer is $t_{i}=\left[t_{1 i}, t_{2 i}, \ldots t_{m i}\right]^{\mathrm{T}} \in R^{m}$. The hidden layer contains $L$ nodes. The activation function $g(x)$ is expressed as follows.

$$
\sum_{i=1}^{L} \beta_{i} g_{i}\left(x_{i}\right)=\sum_{i=1}^{L} \beta_{i} g\left(w_{i} \cdot x_{j}+b_{i}\right)=y_{j} \quad j=1,2, \ldots N,
$$

where, $y_{j}$ represents the output vectors of ELM. $\beta_{i}$ represents the weight vectors connecting the hidden layer and the output layer. $w_{i}$ represents the weight vectors that connects the hidden layer and the input layer. $b_{i}$ and $g\left(w_{i} \cdot x_{j}+b_{i}\right)$ are threshold value and the output value of the hidden node $i$. 
The objective of an ELM is to search for a suitable set of $\beta, \omega$, and $b$ to approximate all training sample pairs with zero error.

$$
\sum_{j=1}^{N}\left\|t_{j}-y_{j}\right\|=\sum_{j=1}^{N}\left\|t_{j}-\sum_{i=1}^{L} \beta_{i} g\left(w_{i} x_{j}+b_{i}\right)\right\|=0 .
$$

Formula (7) can be expressed as:

$$
\begin{gathered}
H \beta=T \\
H=\left[\begin{array}{c}
g\left(w_{1} x_{1} b_{1}\right) g\left(w_{2} x_{1} b_{2}\right) \cdots g\left(w_{L} x_{1} b_{L}\right) \\
g\left(w_{1} x_{2} b_{1}\right) g\left(w_{2} x_{2} b_{2}\right) \cdots g\left(w_{L} x_{2} b_{L}\right) \\
\cdots \\
g\left(w_{1} x_{N} b_{1}\right) g\left(w_{2} x_{N} b_{2}\right) \cdots g\left(w_{L} x_{N} b_{L}\right)
\end{array}\right]_{N \times L}, \\
\beta=\left[\beta_{1}, \beta_{2}, \ldots \beta_{L}\right]_{L \times 1}^{-1} \text {, and } T=\left[t_{1}, t_{2}, \ldots t_{L}\right]_{L \times 1}^{-1},
\end{gathered}
$$

where $H$ is the output matrix of the hidden layer; $\beta$ is the weights vector connecting the hidden layer nodes with the output layer neurons; and $T$ represents the target output.

When the activation function is infinite differentiable, ELM analytically calculates the hidden-output weights by searching for a minimal norm least square solution of the following linear equation.

$$
\begin{gathered}
\|H \hat{\beta}-T\|=\min _{\beta}\|H \beta-T\|, \\
H \beta=T, \\
\hat{\beta}=H^{\mathrm{T}} T,
\end{gathered}
$$

where $H^{\mathrm{T}}$ denotes the Moore-Penrose generalized inverse of the hidden-layer output matrix $H$.

\subsection{CSO-ELM Model}

In the basic ELM model, when the number of hidden layer nodes is fixed, the input weights and hidden layer deviations of the network structure are randomly determined, which affects the stability of the model itself. After using CSO to improve ELM algorithm, the number of hidden layer nodes, input weights and thresholds value of ELM model are adaptively selected. The flow chart is shown in Figure 1. In the CS algorithm, $N$ nests are set. Then, round the position value as the number of the hidden nodes $M$. After inputting the sample data, a set of input weight matrices $W$ for ELM networks will be generated. Then, the threshold value of the hidden layer $b$ will be obtained, and the model output the weight matrices $\beta$. The prediction error calculated by the sample data will be the fitness value of the present nest. At the end of each iteration, the optimal nest location is preserved, and the values of $W, b$, and $\beta$ are outputted. After satisfying the iteration termination conditions, the fitness values of nests are compared. Finally, the optimal position of the bird's nest are obtained, and the corresponding values of $W, b, \beta$ will be exported. The improved ELM method operates as follows.

1. Set the parameters of the CSO algorithm. The probability parameter of the nest being discovered is set as $p_{a}$. The initial positions of $N$ nests are generated as nest $t_{0}=\left[x_{1}^{0}, x_{2}^{0}, \ldots, x_{N}^{0}\right]$. Round the position values to $N$ different values as the number of nodes of the ELM hidden layer. Input the sample and calculate the root mean square error (RMSE) as the corresponding optimal fitness value $F_{0}$. The maximum number of iterations is max_it.

2. Choose the last optimum nest position $x_{i}$. Search for the nest position $j$ through the Lévy flight, and round the position value as the number of ELM hidden nodes. Then, calculate $F_{j}$ and compare it with $F_{i}$ to keep the better solution.

3. Generate random number $p_{r}$ and compare it with $p_{a}$. If $p_{r}>p_{a}$, choose the nest position randomly and replace the worst one. Otherwise, nothing changes. 
4. Stop searching after the number of iterations is satisfied.

5. Select the position with minimum fitness as the number of hidden layer nodes of ELM and output the corresponding values of $W, b$ and $\beta$. The electric power substitution market potential prediction model cased on CSO-ELM is established.

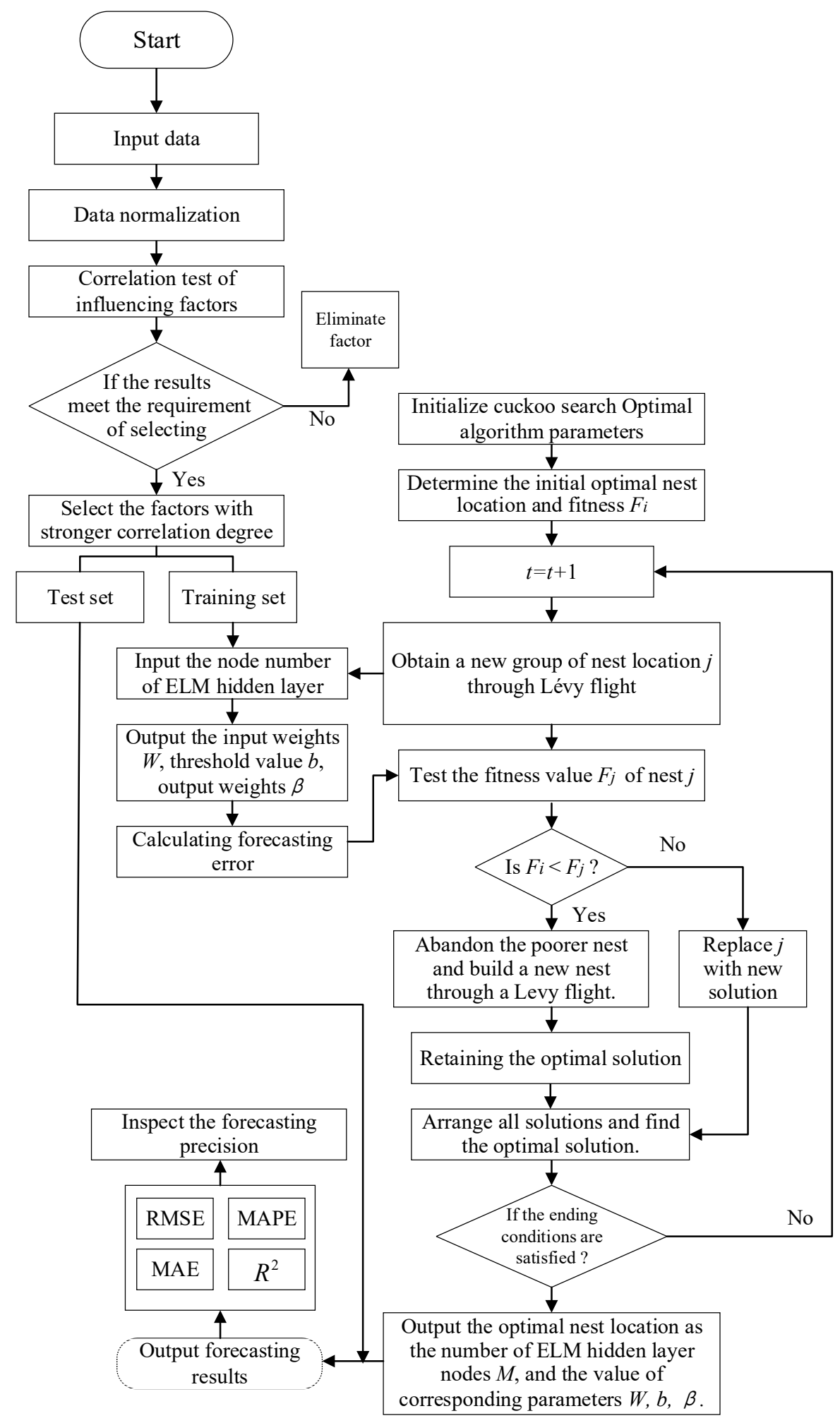

Figure 1. Outline of procedure of proposed method. 


\section{Case Study and Results}

\subsection{Validation Test of Forecasting Model}

The proposed forecasting method is tested by historical data inputting. The data used in this research is collected from both the "Statistical Yearbook of China" and the "Annual Report of Electric Power Industry" for the latest 20 years. Given the development of electric power substitution projects being affected by many factors, Pearson correlation test is carried out for test the correlations of each factor. Factors with high correlation are used as input data of the forecasting model to accurately predict the market potential of electric power substitution projects. The historical data are shown in the Table 3. The correlation test of each factor is carried out by Statistical Product and Service Solutions (SPSS) software and the results are shown in Table 3 and Figure 2.

Table 3. Correlation degree of influence factors and market potential of electric power substitution.

\begin{tabular}{|c|c|c|c|c|c|}
\hline & Factors & $\begin{array}{l}\text { Correlation } \\
\text { Degree }\end{array}$ & & Factors & $\begin{array}{l}\text { Correlation } \\
\text { Degree }\end{array}$ \\
\hline 1 & GDP per capita & 0.966 & 5 & Renewable Energy Generation & 0.931 \\
\hline 2 & $\begin{array}{c}\text { Electricity } \\
\text { Consumption }\end{array}$ & 0.987 & 6 & Renewable Energy Installed Capacity & 0.915 \\
\hline 3 & $\begin{array}{c}\text { Electric Power } \\
\text { Installed Capacity }\end{array}$ & 0.968 & 7 & $\begin{array}{l}\text { Annual Increment Investment in } \\
\text { Electric Power Industry }\end{array}$ & 0.963 \\
\hline 4 & Carbon Emissions & 0.985 & 8 & $\begin{array}{c}\text { Annual Increment Investment in } \\
\text { Power Grids }\end{array}$ & 0.975 \\
\hline
\end{tabular}

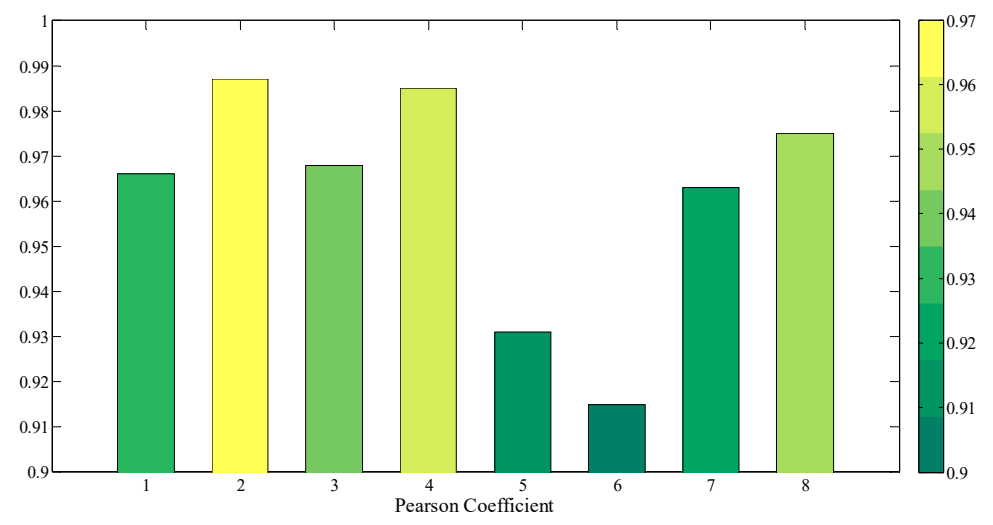

Figure 2. Pearson coefficient.

The research is used to forecast the market potential of power substitution projects in 2018-2030. A forecasting model of extreme learning machine based on the cuckoo search optimization is constructed. By taking historical data of 1998-2017 as an example, the validity of this model is tested. Due to the substitution work being a gradual process-when the CSO-ELM model is used to forecast the market potential of electric power substitution projects-the electric power substitution amount in every year in the future is forecasted in turn. When forecasting, the data of the target year is added to the training set of the model to give out more accurate results.

Data from 1998 to 2012 is chosen as the training set, and data from 2013 to 2017 is used as the test set. The BP neural network, ELM and CSO-ELM forecasting models are all used to forecast the electric power substitution from 2013 to 2017. ELM and BP neural network are introduced as the contrast algorithm, and the parameters are set to be at the optimal values after comparison. In setting the parameters settings of BPNN, the number of neurons in hidden layer is set as 6 . In addition, the tansig function is used as the transfer function. The output layer is set as the purelin function. The training times are set to 1000, and the precision target is set as 0.001. In the ELM forecasting model, the number of nodes in hidden layer is 30 , and the activation function is sig function. The initial population number of CSO-ELM is 20 and the maximum iteration number is 200. Historical data is listed in Table 4. 
Table 4. Historical Data.

\begin{tabular}{|c|c|c|c|c|c|c|c|c|c|}
\hline Year & $\begin{array}{c}\text { GDP Per } \\
\text { Capita/Yuan }\end{array}$ & $\begin{array}{l}\text { Electric Power } \\
\text { Consumption/Billion } \\
\text { kWh }\end{array}$ & $\begin{array}{c}\text { Renewable } \\
\text { Energy } \\
\text { Generation } \\
\text { /Billion kWh }\end{array}$ & $\begin{array}{c}\text { Electric Power } \\
\text { Installed } \\
\text { Capacity/Million } \\
\text { kW }\end{array}$ & $\begin{array}{c}\text { Renewable } \\
\text { Energy Installed } \\
\text { Capacity/Million } \\
\text { kW }\end{array}$ & $\begin{array}{c}\text { Annual } \\
\text { Increment } \\
\text { Investment in } \\
\text { Electric Power } \\
\text { Grid/Billion } \\
\text { Yuan }\end{array}$ & $\begin{array}{c}\text { Annual } \\
\text { Increment } \\
\text { Investment in } \\
\text { Electric Power } \\
\text { Industry/Billion } \\
\text { Yuan }\end{array}$ & $\begin{array}{c}\text { Carbon } \\
\text { Emission/Million } \\
\text { Tons }\end{array}$ & $\begin{array}{c}\text { Total } \\
\text { Substitution } \\
\text { Amount/Million } \\
\text { Tons of Standarc } \\
\text { coal }\end{array}$ \\
\hline 2018 & 63,186 & 6844.9 & 1867 & $18,994.8$ & 72,869 & 537.3 & 793 & 10,000 & $36,946.3$ \\
\hline 2017 & 59,660 & 6307.7 & 1832.4 & $17,770.3$ & 65,000 & 535.6 & 801.5 & 9232.6 & $34,133.5$ \\
\hline 2016 & 53,935 & 5919.8 & 1866.6 & $16,457.5$ & 56,400 & 542.6 & 883.6 & 9113.6 & $32,658.7$ \\
\hline 2015 & 50,251 & 5702 & 1509.2 & $15,252.7$ & 48,000 & 464 & 857.6 & 9163.2 & $29,340.4$ \\
\hline 2014 & 47,203 & 5638.37 & 1378.4 & $13,701.8$ & 44,037 & 411.9 & 780.5 & 9204.2 & $29,544.1$ \\
\hline 2013 & 43,852 & 5420.34 & 1151 & $12,576.8$ & 38,700 & 385.6 & 772.7 & 8966.3 & $28,047.9$ \\
\hline 2012 & 40,007 & 4976.26 & 1066.6 & $11,467.6$ & 31,300 & 369.3 & 746.5 & 8792.3 & $24,957.9$ \\
\hline 2011 & 36,403 & 4700.1 & 886.3 & $10,625.3$ & 28,100 & 368.7 & 739.3 & 8104.9 & $24,957.9$ \\
\hline 2010 & 30,876 & 4193.45 & 811.1 & 9664.1 & $25,648.5$ & 344.8 & 705.1 & 7680.7 & $23,060.9$ \\
\hline 2009 & 26,222 & 3703.21 & 703.5 & 8741.0 & $22,302.1$ & 389.8 & 770.2 & 7174.6 & $18,640.4$ \\
\hline 2008 & 24,121 & 3454.13 & 674.8 & 7929.3 & $18,987.3$ & 288.4 & 576.3 & 6710 & $17,530.9$ \\
\hline 2007 & 20,505 & 3271.18 & 591.1 & 7132.9 & 16,128 & 245.1 & 549.3 & 6515.26 & $16,638.6$ \\
\hline 2006 & 16,738 & 2858.8 & 533.8 & 6222 & 14,317 & 209.3 & 528.7 & 6002.7 & $14,271.9$ \\
\hline 2005 & 14,368 & 2494.03 & 476 & 5171.8 & 12,428 & 152.6 & 475.4 & 5447.8 & 8791 \\
\hline 2004 & 12,487 & 2197.14 & 389.8 & 4423.9 & $11,294.7$ & 123.8 & 328.6 & 4782.7 & 1873.6 \\
\hline 2003 & 10,666 & 1903.16 & 326.2 & 3914.1 & $10,163.7$ & 128.4 & 318.1 & 4110.4 & 843.4 \\
\hline 2002 & 9506 & 1646.54 & 302 & 3565.7 & 9102.4 & 154.9 & 229.6 & 3551.3 & 312.6 \\
\hline 2001 & 8717 & 1472.35 & 279.4 & 3384.9 & 8547.5 & 120.3 & 238.4 & 3296.8 & 123.7 \\
\hline 2000 & 7942 & 1347.24 & 260.6 & 3193.2 & 8178.1 & 101.8 & 204.3 & 3139.4 & 38.9 \\
\hline 1999 & 7229 & 1230.52 & 228.4 & 2987.7 & 7533.4 & 91 & 197.8 & 2908.6 & 8.1 \\
\hline 1998 & 6860 & 1159.84 & 196.3 & 2772.8 & 6739.6 & 77.2 & 175.4 & 2991.3 & 0 \\
\hline
\end{tabular}


The fitting results of the three methods are shown in Figure 3. The overall fitting effect of ELM is better than that of BPNN, which is mainly because the forecasting effect of BPNN largely depends on the quality of historical data and the training of a large number of data. The ELM method is an improved BPNN, which maintains the advantages of the fast learning speed and strong generalization ability, and can accurately analyze in the case of small amount of data. The CSO-ELM method combines the global optimization ability of CSO and optimizing transmission weight of ELM, contributing to a better forecasting effect.

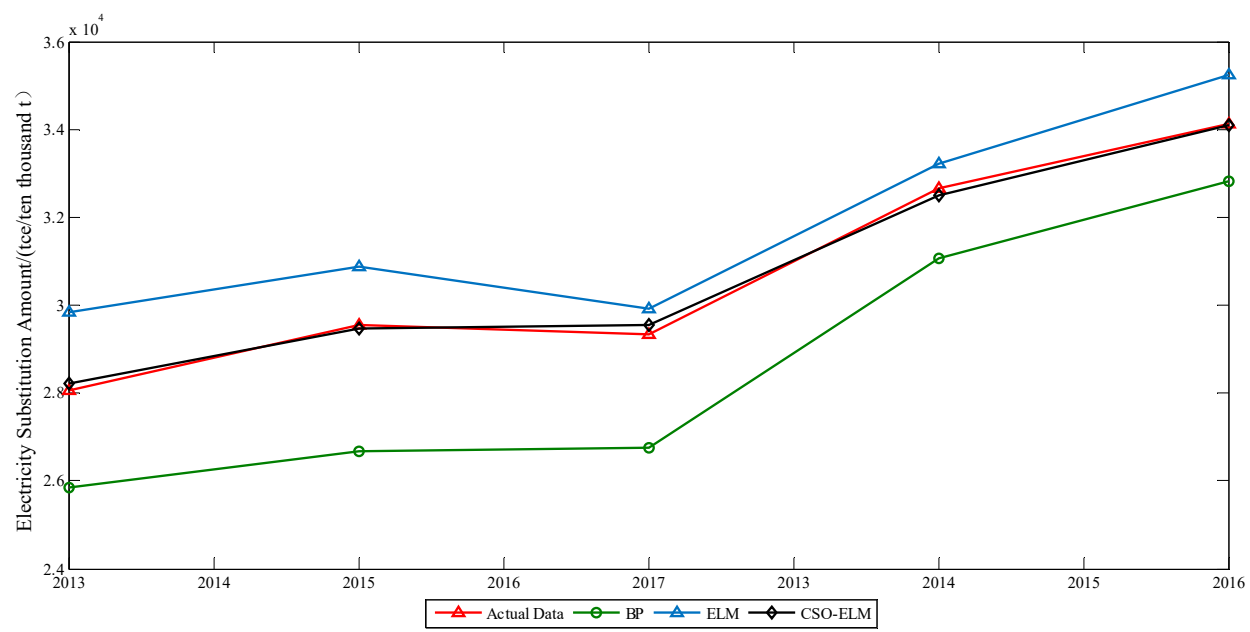

Figure 3. Results of three forecasting models.

To quantify the effect of the forecasting model, Root Mean Square Error (RMSE), Mean Absolute Percentage Error (MAPE), Mean Absolute Error (MAE) and Determining Factor $R^{2}$ are selected as indicators to evaluate the effect of the forecasting model. The calculation of the four error indicators are as follows.

$$
\begin{gathered}
\text { RMSE }=\sqrt{\frac{1}{n} \sum_{i=1}^{n}\left(p_{i}-p^{\prime}{ }_{i}\right)^{2},} \\
M A P E=\frac{1}{n} \sum_{i=1}^{N}\left|\frac{p^{\prime}{ }_{i}-p_{i}}{p_{i}}\right| \times 100 \%, \\
M A E=\frac{1}{n} \sum_{i=1}^{N}\left|p^{\prime}{ }_{i}-p_{i}\right| \\
R^{2}=\frac{\sum_{i=1}^{n}\left(p^{\prime}{ }_{i}-\bar{p}_{i}\right)^{2}}{\sum_{i=1}^{n}\left(p_{i}-\bar{p}_{i}\right)^{2}}
\end{gathered}
$$

where, $p_{i}$ represents the actual electric power substitution amount. $p^{\prime}{ }_{i}$ is the forecasting amount. $\bar{p}_{i}$ is the average of the actual electric power substitution amount, and $n$ is the data size. The calculation results of four indicators are shown in Table 5 and the contrast is shown in Figure 4.

Table 5. Calculation results of error indicators.

\begin{tabular}{ccccc}
\hline Models & RSME & MAPE & MAE & $\mathbf{R}^{\mathbf{2}}$ \\
\hline BPNN & 2186.66 & 7.00 & 2106.62 & 2.35 \\
ELM & 1168.72 & 3.56 & 1071.04 & 1.083 \\
CSO-ELM & 148.10 & 0.44 & 132.08 & 0.92 \\
\hline
\end{tabular}



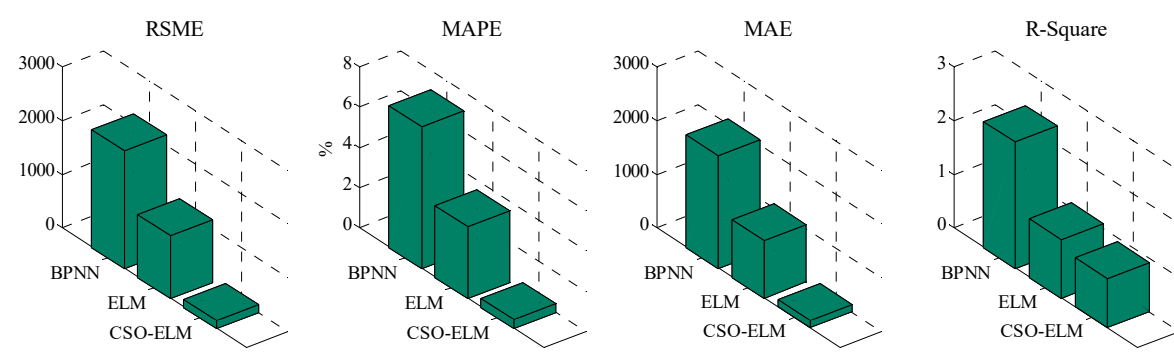

Figure 4. Errors of three methods.

From Table 5 and Figure 4, the constructed CSO-ELM model has a better fitting effect, higher prediction accuracy and less error in the market potential forecasting of electric power substitution. Therefore, using CSO-ELM model to forecast the substitution potential in the next 13 years can reflect the future market potential of electric power substitution projects.

\subsection{Scenarios Setting}

In forecasting the developing potential of future electric power substitution projects, factors such as the costs, policy support and subsidy mechanism are fully considered. Thus, combined with the political objectives of energy-consumption structure optimization, energy conservation and emission reduction, and renewable energy development, four scenarios are designed: basic scenario, high-cost restraint scenario, policies-supported scenario and subsidy weakening scenario.

In basic scenario, according to the development trend of power substitution related factors in 1998-2018, the market development potential of electric power substitution in 2019-2030 is forecasted. In the high-cost restraint scenario, the substitution project will be slowed down by the purchase of expensive equipment and high operating costs. In the policies-support scenario, in order to reduce the cost resistance and alleviate the environmental pressure caused by fossil energy combustion, the government encourages the substitution work by policy mechanism. China's "13th Five-Year Plan for Electric Power Industry" proposed to encourage the developing of electric power substitution and clean energy substitution to expand the proportion of electricity in energy consumption. In addition, the substitution work is supported with appropriate subsidies mechanisms. Relevant subsidy mechanisms can stimulate the rapid development of electric power substitution projects. With the popularization of electric power substitution, the cost would be gradually recovered, and the projects may be profitable, which is when the subsidy mechanism can be weakened or cancelled accordingly, to achieve an independent development of the substitution projects.

In addition, considering the stage characteristics of social and economic development, the forecasting period is divided into three stages: the first stage (2019-2020), the second stage (2021-2025) and the third stage (2026-2030). The parameter settings for each scenario and time period are shown in the Table 6 below. 
Table 6. Scenarios and primary parameter settings.

\begin{tabular}{|c|c|c|c|c|}
\hline Primary Parameters & Basic Scenario & High-Cost Restraint Scenario & Policies-Supported Scenario & Subsidy Weakening Scenario \\
\hline Per Capita GDP & \multicolumn{4}{|c|}{$\begin{array}{l}\text { China's future economy will be at the stage of medium-high speed growth, with GDP per capita growing about } 6.4 \% \text { to } 7.2 \% \text { each year. } \\
\text { GDP per capita is an objective condition and may barely change in all four scenarios. }\end{array}$} \\
\hline Electricity Consumption & $\begin{array}{l}\text { In view of the trend of China's } \\
\text { power consumption, the } \\
\text { electricity consumption is in an } \\
\text { increasing trend with a rate of } \\
4 \% \text {. }\end{array}$ & $\begin{array}{l}\text { At first, electricity consumption } \\
\text { will continue to grow at a rate of } \\
\text { about } 4 \% \text { in the short term. } \\
\text { Then, due to the high cost of the } \\
\text { substitution projects, the growth } \\
\text { rate will be slightly lower than } \\
\text { that in the basic scenario. So, } \\
\text { the increase rate is about } 3.8 \% \text {. }\end{array}$ & $\begin{array}{l}\text { Relevant industrial policies and } \\
\text { subsidy mechanism will bring } \\
\text { positive effects. Electricity } \\
\text { consumption will steadily } \\
\text { increase with a growth trend of } \\
\text { about } 4.2-4.4 \% \text {. }\end{array}$ & $\begin{array}{l}\text { The weakening of subsidies } \\
\text { only occurs in the later stage, so } \\
\text { the impact on electricity } \\
\text { consumption is not significant. } \\
\text { The growth rate of electricity } \\
\text { consumption can still be } \\
\text { maintained at } 4.2 \% \text { to } 4.4 \% \text {. }\end{array}$ \\
\hline Renewable Energy Generation & $\begin{array}{l}\text { The growth of renewable energy } \\
\text { consumption may bring an } \\
\text { increase in electricity } \\
\text { consumption. Based on the } \\
\text { increasing trend, the growth } \\
\text { rate is about } 10 \% \text { to } 12 \% \text {. }\end{array}$ & $\begin{array}{l}\text { The high cost of electric power } \\
\text { substitution projects brings } \\
\text { constraints. Without political } \\
\text { supports, the development of } \\
\text { renewable energy power is } \\
\text { slower, with an annual growth } \\
\text { rate of about } 9.5 \% \text {. }\end{array}$ & $\begin{array}{l}\text { Chinese government proposed } \\
\text { to achieve the target of } 15 \% \text { and } \\
20 \% \text { of substituting fossil energy } \\
\text { by non-fossil energy in } 2020 \text { and } \\
2030 \text { respectively. With proper } \\
\text { subsidies, the growth rate can } \\
\text { reach } 12 \% \text { to } 13 \% \text {. }\end{array}$ & $\begin{array}{l}\text { The goal of developing } \\
\text { renewable energy remains } \\
\text { unchanged, but it is assumed } \\
\text { that the subsidy coefficient of } \\
\text { renewable energy will gradually } \\
\text { decrease in the next } 13 \text { years. } \\
\text { The growth rate is slightly } \\
\text { lower, about } 11.8 \% \text { to } 12.5 \% \text {. }\end{array}$ \\
\hline $\begin{array}{l}\text { Electric Power Installed } \\
\text { Capacity }\end{array}$ & $\begin{array}{l}\text { With the gradual saturation of } \\
\text { power-installed capacity, the } \\
\text { installed capacity shows the } \\
\text { trend of deceleration increase, at } \\
\text { a rate of } 4 \% \text { to } 4.6 \% \text {. }\end{array}$ & $\begin{array}{l}\text { Due to the high cost of electric } \\
\text { power substitution projects and } \\
\text { the risk of loss (no subsidy } \\
\text { given), the growth rate of } \\
\text { electric energy consumption is } \\
\text { slower. The construction of } \\
\text { newly-built electric assets will } \\
\text { be affected, and the growth rate } \\
\text { will slow down to about } 3.2 \% \text { to } \\
4.3 \% \text {. }\end{array}$ & $\begin{array}{l}\text { Renewable energy may increase } \\
\text { its installed capacity. The } \\
\text { growth rate of installed capacity } \\
\text { is about } 4.1 \% \text { to } 4.8 \% \text {. }\end{array}$ & $\begin{array}{l}\text { Similar to the } \\
\text { policies-supported scenario. }\end{array}$ \\
\hline
\end{tabular}


Table 6. Cont.

\begin{tabular}{|c|c|c|c|c|}
\hline Primary Parameters & Basic Scenario & High-Cost Restraint Scenario & Policies-Supported Scenario & Subsidy Weakening Scenario \\
\hline Per Capita GDP & \multicolumn{4}{|c|}{$\begin{array}{l}\text { China's future economy will be at the stage of medium-high speed growth, with GDP per capita growing about } 6.4 \% \text { to } 7.2 \% \text { each year. } \\
\text { GDP per capita is an objective condition and may barely change in all four scenarios. }\end{array}$} \\
\hline $\begin{array}{l}\text { Renewable Energy Installed } \\
\text { Capacity }\end{array}$ & $\begin{array}{l}\text { Electric power substitution } \\
\text { strategy brings positive effects } \\
\text { on developing renewable } \\
\text { energy However, the growth } \\
\text { rate, which is about } 8.3 \% \text { to } 9 \% \text {, } \\
\text { is limited by the social demand. }\end{array}$ & $\begin{array}{l}\text { If technology improvement is } \\
\text { the only driving force and no } \\
\text { subsidy incentive is given, the } \\
\text { development of renewable } \\
\text { energy will be restrained. The } \\
\text { growth rate of renewable energy } \\
\text { installed capacity will be slow, } \\
\text { about } 5.2 \% \text {. }\end{array}$ & $\begin{array}{l}\text { Supported by policies and } \\
\text { subsidies, the renewable energy } \\
\text { installed capacity will increase. } \\
\text { The increasing rate is about } 8.4 \% \\
\text { to } 12.54 \% \text {. }\end{array}$ & $\begin{array}{l}\text { The renewable energy installed } \\
\text { capacity will be slightly lower } \\
\text { than that in the } \\
\text { policies-supported scenario, } \\
\text { and the increasing rate is about } \\
8 \% \text { to } 12 \% \text {. }\end{array}$ \\
\hline $\begin{array}{l}\text { Annual Increment Investment } \\
\text { in Power Grid }\end{array}$ & $\begin{array}{l}\text { The increase in renewable } \\
\text { energy power will bring } \\
\text { investments in power grid } \\
\text { construction. The growth rate of } \\
\text { power-grid construction } \\
\text { investment is about } 1.7 \% \text { to } \\
2.3 \% \text {. }\end{array}$ & $\begin{array}{l}\text { Compared with the basic } \\
\text { scenario, less investment will be } \\
\text { made to construct the power } \\
\text { grid for accessing renewable } \\
\text { power, so the growth rate is } \\
\text { about } 1.6 \% \text { to } 2 \% \text {. }\end{array}$ & Same as the basic scenario. & Same as the basic scenario. \\
\hline $\begin{array}{l}\text { Annual Increment Investment } \\
\text { in Electric Power Industry }\end{array}$ & $\begin{array}{l}\text { According to historical data } \\
\text { from } 1998 \text { to } 2017 \text {, the growth } \\
\text { rate of the annual investment in } \\
\text { power industry will gradually } \\
\text { decrease in the future, about } \\
5.2 \% \text { to } 6.1 \% \text {. }\end{array}$ & $\begin{array}{l}\text { The volume ratio of the annual } \\
\text { investment under this scenario } \\
\text { is slightly lower than that of the } \\
\text { basic scenario, which is about } \\
4.1 \% \text { to } 4.4 \% \text {. }\end{array}$ & $\begin{array}{l}\text { Due to subsidy mechanism, } \\
\text { more investment enters into } \\
\text { power industry. The growth } \\
\text { rate of electricity investment } \\
\text { will slow down in the future, } \\
\text { which is about } 6.2 \% \text { to } 7.3 \% \text {. }\end{array}$ & $\begin{array}{l}\text { The investment will increase } \\
\text { progressively at a rate about } \\
6.2 \% \text { to } 7.1 \% \text {, which is slightly } \\
\text { lower than that of the } \\
\text { policies-supported scenario. }\end{array}$ \\
\hline Carbon Emissions & $\begin{array}{l}\text { According to the carbon } \\
\text { emission situation in the past } 20 \\
\text { years, assume that the trend of } \\
\text { carbon emission reduction in } \\
\text { the future is about } 2.1 \% \text { to } 2.5 \% \text {. }\end{array}$ & $\begin{array}{l}\text { While high cost brings } \\
\text { resistance to the development of } \\
\text { renewable energy, it will also } \\
\text { weaken the environmental } \\
\text { benefits and reduce the } \\
\text { efficiency of carbon emission } \\
\text { reduction indirectly. The trend } \\
\text { of emission reduction is about } \\
1.4 \% \text { to } 1.7 \% \text {. }\end{array}$ & $\begin{array}{l}\text { The development of renewable } \\
\text { energy will effectively reduce } \\
\text { carbon emissions. Therefore, in } \\
\text { this scenario, the reduction rate } \\
\text { of carbon emissions is about } \\
3.6 \% \text { to } 4 \% \text {. }\end{array}$ & $\begin{array}{l}\text { The decreasing rate is slightly } \\
\text { lower than that in } \\
\text { policies-supported scenario, at } \\
\text { about } 3.6 \% \text { to } 3.8 \%\end{array}$ \\
\hline
\end{tabular}




\subsection{Results of Scenarios and Discussion}

In the four different scenarios, the amount of electric power substitution shows significant growth trends before 2030. Affected by electricity consumption, renewable energy generation and other factors, the market potential of electric power substitution has broad market prospects. Electric energy can effectively reduce carbon emissions to a minimum through scale-effect and technological means (such as smart grid) in power production and transmission section. Therefore, the realization of electricity substitution is a low-carbon energy development and utilization strategy as a whole, which will inevitably have a positive impact on China's low-carbon economy. Restricted by high construction costs and operation fees, people's subjective acceptance of electric power substitution project is relatively low, which brings difficulties in popularizing. The forecasting results are shown in Table 7.

Table 7. Multi-scenarios forecasting result.

\begin{tabular}{ccccc}
\hline \multirow{2}{*}{ Year } & \multicolumn{3}{c}{ Substituting Amount } \\
\cline { 2 - 5 } & Basic Scenario & High-Cost Restraint Scenario & Policies-Supported Scenario & Subsidy Weakening Scenario \\
\hline $\mathbf{2 0 1 9}$ & 382.7618 & 373.5561 & 385.4891 & 385.618 \\
$\mathbf{2 0 2 0}$ & 396.7616 & 378.3581 & 412.536 & 415.7296 \\
$\mathbf{2 0 2 1}$ & 415.1382 & 389.6555 & 429.1873 & 428.0477 \\
$\mathbf{2 0 2 2}$ & 422.5893 & 401.019 & 440.9279 & 441.7451 \\
$\mathbf{2 0 2 3}$ & 442.4443 & 417.0991 & 463.5306 & 463.9663 \\
$\mathbf{2 0 2 4}$ & 472.7527 & 431.8294 & 491.1256 & 492.1716 \\
$\mathbf{2 0 2 5}$ & 493.6642 & 445.6533 & 514.5227 & 515.4268 \\
$\mathbf{2 0 2 6}$ & 523.7452 & 458.8113 & 543.0128 & 546.7548 \\
$\mathbf{2 0 2 7}$ & 554.6676 & 473.256 & 576.6824 & 587.3033 \\
$\mathbf{2 0 2 8}$ & 584.2509 & 489.9646 & 608.059 & 618.2991 \\
$\mathbf{2 0 2 9}$ & 604.934 & 524.5843 & 640.7256 & 652.0776 \\
$\mathbf{2 0 3 0}$ & 628.2181 & 538.1725 & 680.3083 & 693.8293 \\
\hline
\end{tabular}

In all four scenarios, substituting electricity shows significant increase. In the first stage, the growth rate is relatively small. During this period, the subsidies of the subsidy weakening scenario have not been weakened, so there is little difference with other scenarios. In the second stage, due to social development and technological progress, electric power substitution projects begin to have a certain scale of promotion. The substitute electricity in the high-cost restraint scenario shows the slowest increase. In the policies-supported scenario, the substitute electricity amount shows accelerated growth, while the subsidy mechanism in the subsidy weakening scenario begins to fade down slightly. In the third stage, after the promotion of the first two stages, the electric power substitution project has a certain scale effect, and the electric power substitution quantity shows a trend of accelerating growth.

As can be seen in Figure 5, the process of electric power substitution in the policies-support scenario and subsidy weakening scenario is significantly higher than that in the basic scenario, which shows that the government support is very important in substitution promoting work. In addition, the substitution amount in the high-cost restraint scenario is the least one in all four scenarios, about 538.17 million tons of standard coal in 2030. High costs lower the residents' acceptance of projects, and the promotion power of manufacturers is insufficient without any subsidies given. In the policies-support scenario, the government supports by giving subsidies in equipment purchasing, installation, operation and maintenance process-so that the projects are promoted-with the most increment in electricity amount, reaching 693.8 million tons of standard coal in 2030. Differing from the policies-support scenario, changes after power substitution reaching certain scale effects are considered in the subsidy weakening scenario. With the popularization of electric power substitution projects and technical progress, government support gradually reduced to raise independence of the substitution industry, as can be seen from the curve of the subsidy weakening scenario in Figure 5. The increasing trend of substitute electricity under the subsidy weakening scenario is similar to that of the policies-support scenario. With the reduction of subsidies, the amount of electric power substitution become less than that in the policies-support scenario after 2023, but still higher than that in the basic scenario, which shows the effectiveness of subsidy weakening. 


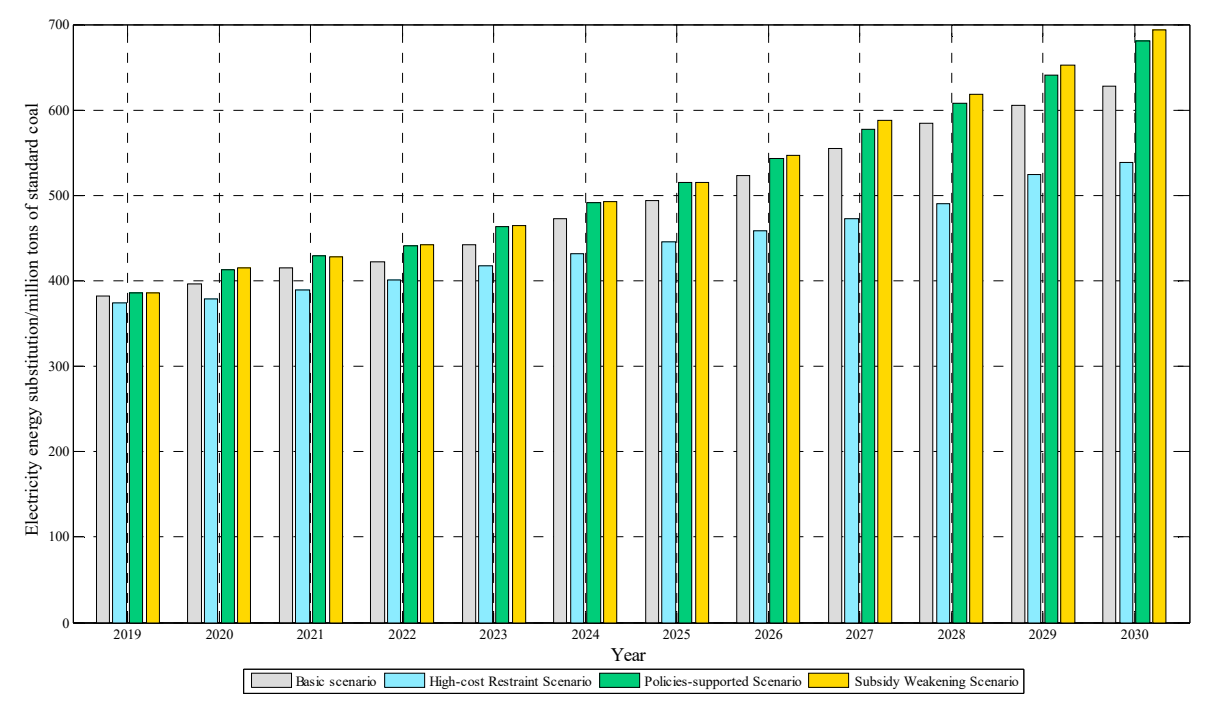

Figure 5. Forecasting results of electric power substitution under all scenarios (million tons of standard coal).

In the early stage of developing electric power substitution, the main fields for promotion are concentrated on substitutions of coal, coal-fired boilers and coal-fired heating-where technology is relatively mature. In the middle and later stages, electric power substitution work turns to household electrification, substitution to internal-combustion engines by electricity and substitution to oil-fired vehicle by electric vehicle. Implementing electric power substitution will bring significant changes in China's energy consumption structure, significantly reducing the proportion of oil and natural gas consumption and significantly reduce carbon emissions.

\section{Conclusions}

Electric power substitution is important in environmental management and for optimizing energy structure. Market forecasting on electric power substitution projects is conducive to the government and society to develop and promote the substituting work. Therefore, a market potential forecast model of electric power substitution based CSO-ELM method is proposed. Firstly, the validity of the influencing factors on the potential of power substitution development are verified through correlation test. Secondly, combined with CSO algorithm, the ELM method is improved, which overcomes the limitation of the search ability of the original ELM and improves the forecasting accuracy. In addition, compared with BP, ELM and other forecasting models, the proposed CSO-ELM model has lower error and deviation, showing better forecasting effect. Due to government support and the limitations of industrial development, four scenarios were designed to give specific forecasting results to show how different factors influence the development of electric power substitution projects. In addition, the forecasting time period was divided into three stages to take on further analysis. Through comparative analysis of the forecasting results under different scenarios, some suggestions for promoting electric power substitution are proposed below.

(1). Compared with the direct utilization of coal, oil and other traditional energy sources on the user side, electricity production has lower carbon emissions. Therefore, it is of great significance to promote social energy conservation and emission reduction, and to solve the Urban Haze problem as well.

(2). Subsidies would help reduce the actual costs for users in applying electric power substitution projects, which would arouse users and producers' initiative. For improving the economic benefits, proper electricity price mechanism and corresponding subsidies should be made to expand the market scale of substitution projects. 
(3). The forecasting results in the subsidy weakening scenario show that the substituting electricity amount keeps increasing with weakened subsidies due to the scale effect built in the early stage with full subsidy mechanism. Therefore, while promoting, the government can change the subsidy coefficient flexibly according to the economic benefits of electric power substitution projects. Adjustable subsidy coefficient can also reduce the financial burden of the government, and encourage the industry to achieve independent development.

(4). Instead of applying renewable energy power into electricity energy substitution, renewable power can be used in the generation side to substitute the thermal units as well. The application of cleaner power will help optimize the structure of the whole power industry chain, and realize high proportion and high efficiency utilization of renewable energy.

(5). Another way to promote the development of renewable energy is to improve the generation cost of traditional generators. By improving the standard of pollutant emission payments and applying Renewable Portfolio Standards (RPS) and green power certifications, the utilization of renewable energy will be further improved.

Author Contributions: Conceptualization, J.W. and G.D.; methodology, K.W.; software, K.W.; validation, G.D., Z.T. and L.P.; formal analysis, J.W.; investigation, Q.T.; resources, L.J.; data curation, K.W.; writing-original draft preparation, J.W.; writing-review and editing, G.D. and Q.T.; K.W.; supervision, Z.T.; project administration, G.D. and L.J.; funding acquisition, Z.T. and L.J.

Funding: This work was partially supported by Supported by the Project funded by China Postdoctoral Science Foundation (2019M650024), the National Nature Science Foundation of China (Grant Nos. 71904049,71874053, 71573084), the Beijing Social Science Fund(18GLC058) and the 2018 Key Projects of Philosophy and Social Science Research, Ministry of Education, China (18JZD032).

Acknowledgments: Teachers and classmates helped complete this paper. We would like to express our gratitude to them for their help and guidance.

Conflicts of Interest: The authors declare no conflict of interest.

\section{References}

1. Zhihua, W.; Peng, A.; Fangting, X. The coordination of three institutions to promote electric power replacement. Power Demand Side Manag. 2016, 18, 103-104.

2. Qing, W.; Feng, W.; Yan, M. The green power supply office construction based on clean alternative and electric power alternative. Power Demand Side Manag. 2016, 18, 36-39.

3. Pu, L.; Wang, X.; Tan, Z.; Wu, J.; Long, C.; Kong, W. Feasible electricity price calculation and environmental benefits analysis of the regional nighttime wind power utilization in electric heating in Beijing. J. Clean. Prod. 2019, 212, 1434-1445. [CrossRef]

4. Shou-bo, X.U. Review of reformation of China's energy development strategy. Power Syst. Clean Energy 2008, $24,1-5$.

5. Ming, L.; Diangang, H.; Youxue, Z. Research and practice of renewable energy local consumption mode in Gansu Province based on "double alternative" strategy. Power Grid Technol. 2016, 40, 2991-2997.

6. Song, X.; Kening, C.; Li, M.; Menghua, F. Key Issues in China's Demand Side Resources Promoting Non-Hydro Renewable Power Intermittent. J. Tech. Econ. Manag. 2018, 4, 87-92.

7. Haibo, P.; Dezhi, L.; Wanjiao, H.; Wangzhu, G. Electric power replacement technologies facing new energy accommodation. Power Demand Side Manag. 2016, 18, 45-48.

8. Cai, W.; Liu, C.; Lai, K.H.; Li, L.; Cunha, J.; Hu, L. Energy performance certification in mechanical manufacturing industry: A review and analysis. Energy Convers. Manag. 2019, 186, 415-432. [CrossRef]

9. Cai, W.; Li, L.; Jia, S.; Liu, C.; Xie, J.; Hu, L. Task-Oriented Energy Benchmark of Machining Systems for Energy-Efficient Production. Int. J. Precis. Eng. Manuf. Green Tech. 2019, 1-14. [CrossRef]

10. Wu, J.; Yan, J.; Jia, H.; Nikos, H.; Ned, D.; Hongbin, S. Integrated Energy Systems. Appl. Energy 2016, 167, 155-157. [CrossRef]

11. Hui, S.; Xiaoping, W. Research on Renewable Energy Substitute Model Based on System Dynamics in China. Math. Pract. Theory 2013, 10, 58-70. 
12. Qian, S.; Xiaodong, L. Identifying the underpin of green and low carbon technology innovation research: A literature review from 1994 to 2010. Technol. Forecast. Soc. Chang. 2013, 80, 839-864.

13. He, H.; Jim, C.Y. Coupling model of energy consumption with changes in environmental utility. Energy Policy 2012, 43, 235-243. [CrossRef]

14. Raul, A.B. Fossil fuels, alternative energy and economic growth. Econ. Model. 2018, 75, 196-220.

15. Yan, L.; Bo, Y.; Fuyan, H. Study on renewable energy dynamic state growth model on sustainable development theory. China Soft Sci. 2011, S1, 240-246.

16. Pina, A.; Baptista, P.; Silva, C.; Ferrão, P. Energy reduction potential from the shift to electric vehicles: The Flores island case study. Energy Policy 2014, 67, 37-47. [CrossRef]

17. Bhupendra, K.V.; Sangle, S. What drives successful implementation of pollution prevention and cleaner technology strategy? The role of innovative capability. J. Environ. Manag. 2015, 155, 184-192. [CrossRef]

18. Zhong, W.; Qiang, L.; Hongtao, X. Efficiency evaluation of alternative energy in heat supply sustem. J. Zhejiang Univ. Technol. 2015, 43, 508-511.

19. Pokharel, S. Promotional issues on alternative energy technologies in Nepal. Energy Policy 2003, 31, 307-318. [CrossRef]

20. Zuofeng, L. The research and practice of electric energy alternative in Jiangsu. Power Demand Side Manag. 2016, 18, 1-3.

21. Xiaoli, L.; Wenbing, L.; Haiming, Z. Alternative energy in the energy network. Smart Grid 2015, 3, 1192-1196.

22. Wencong, L.; Changcai, X. The effect of carbon emissions trading market on the clean production in various regions in China [J/OL]. Acta Ecol. Sin. 2019, 18, 1-9. Available online: http://kns.cnki.net/kcms/detail/11. 2031.Q.20190704.1606.068.html (accessed on 21 August 2019).

23. Wei, Y.; Xia, L.; Pan, S.; Wu, J.; Zhang, X.; Han, M.; Zhang, W.; Xie, J.; Li, Q. Prediction of occupancy level and energy consumption in office building using blind system identification and neural networks. Appl. Energy 2019, 240, 276-294. [CrossRef]

24. Kostmann, M.; Härdle, W.K. Forecasting in Blockchain-Based Local Energy Markets. Energies 2019, $12,2718$. [CrossRef]

25. Li, Y.; Han, Y.; Wang, J.; Zhao, Q. A MBCRF Algorithm Based on Ensemble Learning for Building Demand Response Considering the Thermal Comfort. Energies 2018, 11, 3495. [CrossRef]

26. Zhouchun, W.; Xiaochen, Z.; Yuqing, M.; Xinyan, Z. A hybrid model based on modified multi-objective cuckoo search algorithm for short-term load forecasting. Appl. Energy 2019, 237, 896-909.

27. Changhao, X.; Jian, W.; McMenemy, K. Short, medium and long term load forecasting model and virtual load forecaster based on radial basis function neural networks. Electr. Power Energy Syst. 2010, 32, 743-750.

28. Shan, Y.; Fu, Q.; Geng, X.; Zhu, C. Combined forecasting of photovoltaic power generation in microgrid based on the improved BP-SVM-ELM and SOM-LSF with particlization. Proc. CSEE 2016, 36, 3334-3343.

29. Chen, K.; Yu, J. Short-term wind speed prediction using an unscented Kalman filter based state-space support vector regression approach. Appl. Energy 2014, 113, 690-705. [CrossRef]

30. Lee, Y.; Tong, L. Forecasting energy consumption using a grey model improved by incorporating genetic programming. Energy Convers. Manag. 2011, 52, 147-152. [CrossRef]

31. Ferlito, S.; Adinolfi, G.; Graditi, G. Comparative analysis of data-driven methods online and offline trained to the forecasting of grid-connected photovoltaic plant production. Appl. Energy 2017, 205, 116-129. [CrossRef]

32. Yu, F.; Xu, X. A short-term load forecasting model of natural gas based on optimized genetic algorithm and improved BP neural network. Appl. Energy 2014, 134, 102-113. [CrossRef]

33. Guochang, F.; Lixin, T.; Min, F.; Mei, S. Impacts of new energy on energy intensity and economic growth. Syst. Eng. Theory Pract. 2013, 33, 2795-2803.

34. Qingyou, Y.; Mingliang, Z.; Xinfa, T. Electrical energy alternative research based on the cost utility analysis. Oper. Res. Manag. Sci. 2015, 24, 176-183.

35. Yi, S.; Mo, S.; Baoguo, S.; Fang, C. Electric energy substitution potential analysis method based on particle swarm optimization support vector machine. Power Syst. Technol. 2017, 41, 1767-1771.

36. Hang, Y. Energy Conservation and Emission Reduction Environment Power to Substitute Other Energy Evaluation Method Research; North China Electric Power University: Beijing, China, 2013.

37. Jincheng, Z. Analysis on Potential and Environmental Benefit of Rural Power Substitute; North China Electric Power University: Beijing, China, 2015. 
38. Yanmei, L.; Zeng, C. Study on Regional Electric Energy Substitution Potential Evaluation Based on the TOPSIS Method Improved by Connection Degree. Power Syst. Technol. 2019, 43, 687-695.

39. Dongli, C.; Yue, Y.; Zhixiang, L. Application and Efficiency Evaluation of Alternative Energy. Power Syst. Clean Energy 2011, 27, 30-34.

40. Yang, X.S.; Deb, S. Cuckoo search via Lévy flights. In Proceedings of the 2009 World Congress on Nature \& Biologically Inspired Computing (NaBIC 2009), Coimbatore, India, 9-11 December 2009; pp. 210-214.

(C) 2019 by the authors. Licensee MDPI, Basel, Switzerland. This article is an open access article distributed under the terms and conditions of the Creative Commons Attribution (CC BY) license (http://creativecommons.org/licenses/by/4.0/). 